Sohari

\title{
ETOS KERJA DALAM PERSPEKTIF ISLAM
}

\begin{abstract}
Abstrak
Karakteristik etos kerja Islami digali dan dirumuskan berdasarkan konsep iman sebagai fondasi dan amal shalih sebagai bentuk yang terbangun di atasnya, dengan memberi prioritas penekanan pada etos kerja beserta prinsip-prinsip dasarnya. Etos kerja apapun menurut pemahaman Qur'ani tidak dapat menjadi Islami bila tidak dilandasi konsep iman dan amal shalih, sebab sekalipun kerja itu bermanfaat dan bersifat keduniaan bagi banyak orang, tanpa dasar iman tidak akan membuahkan pahala di akhirat kelak.

Dalam aplikasinya di masyarakat, etos kerja seringkali tidak sesuai dengan ajaran yang telah dicontohkan oleh Nabi Muhammad SAW, misalnya bekerja tidak memperhitungkan halal dan haramnya. Dalam ajaran Islam ditentukan bahwa usaha yang terbaik adalah usaha seseorang dengan tangannya sendiri dan setiap jual beli yang mabrur (tidak ada tipu daya).
\end{abstract}

Kata Kunci: Etos, kerja, Islam.

\section{Pendahuluan}

Etos Kerja dapat diartikan sebagai pandangan bagaimana melakukan kegiatan yang bertujuan mendapatkan hasil atau mencapai kesuksesan. Etos kerja ini perlu dibahas, karena bagi umat Islam sangat diperlukan. Bagaimana umat Islam bisa berhasil dan sukses dalam kehidupan di dunia dan di akhirat manakala tidak adanya jembatan untuk meraih ke arah itu, karena bekerja di dunia, bagi umat Islam merupakan bekal di akhirat kelak. Hidup di surga merupakan tujuan dan impian kesuksesan setiap umat Islam. Kesuksesan di akhirat tersebut juga tidak terlepas dari kesuksesan di dunia melalui ibadah dan amalan sebagaimana diajarkan Islam. ${ }^{1}$

Karakteristik etos kerja yang Islami digali dan dirumuskan berdasarkan konsep iman sebagai fondasi dan amal shalih sebagai bentuk yang terbangun di atasnya, dengan memberi prioritas penekanan pada etos kerja beserta prinsipprinsip dasarnya. Etos kerja apapun menurut pemahaman Qur'ani tidak dapat menjadi Islami bila tidak dilandasi konsep iman dan amal shalih, sebab sekalipun kerja itu bermanfaat dan bersifat keduniaan bagi banyak orang, tanpa dasar iman tidak akan membuahkan pahala di akhirat kelak. ${ }^{2}$ 
Islam mendidik pengikutnya agar cinta bekerja sebagaimana firman Allah dalam surat al-Jumu'ah ayat 10:

"Apabila telah ditunaikan shalat, maka bertebaranlah kamu di muka bumi; dan carilah karunia Allah dan ingatlah Allah banyak-banyak supaya kamu beruntung."

Dari ayat di atas jelas bahwa Allah menghendaki umat Islam untuk bekerja keras dalam mencari karunia/rezeki dari Allah. Dan Allah juga mengisyaratkan di samping manusia mencari rizki, namun tidak boleh melupakan Allah sebagai Pencipta dan Yang Maha Kuasa.

Etos kerja Islami yang tinggi hendaknya dilandasi dengan moralitas yang baik, seperti amanat (jujur), tanggungjawab, menepati janji, hidup hemat, memperhtikan tiga dimensi waktu yakni masa lalu, sekarang dan masa yang akan datang, penuh kesabaran dan tawakkal kepada Allah. ${ }^{4}$

Dalam melakukan bisnis atau apaun bentuk usahanya seseorang tidak boleh melakukan H3T (Halal, Haram, Hantam Terus), karena itu Islam memberikan jalan yang terbaik yakni harus berusaha dengan cara yang baik, tidak boleh memakan harta Riba dan tidak boleh mencampur antara yang hak dan yang batil. Dalam Al-Qur'an surat Al-Baqarah, ayat: 275 Allah berfirman yang artinya:

"Orang-orang yang makan (mengambil) riba tidak dapat berdiri melainkan seperti berdirinya orang yang kemasukan syaitan lantaran (tekanan) penyakit gila. keadaan mereka yang demikian itu, adalah disebabkan mereka Berkata (berpendapat), Sesungguhnya jual beli itu sama dengan riba, padahal Allah Telah menghalalkan jual beli dan mengharamkan riba. Orang-orang yang telah sampai kepadanya larangan dari Tuhannya, lalu terus berhenti (dari mengambil riba), maka baginya apa yang telah diambilnya dahulu (sebelum datang larangan); dan urusannya (terserah) kepada Allah. orang yang kembali (mengambil riba), maka orang itu adalah penghuni-penghuni neraka; mereka kekal di dalamnya."

Agar tidak terkontaminasi oleh praktek kotor dalam praktek jual beli, maka Allah mengutus Nabi Muhammad saw. Sebagai Rasul-Nya untuk memberikan tuntunan praktis terhadap pembeli dan penjual, serta tentang barang-barang yang boleh diperjual-belikan dan yang barang-barang yang dilarang diperdagangkan. Beliau juga menjelaskan kepada ummatnya tentang usaha yang baik. ${ }^{6}$

Demikian juga tentang sikap dan tingkah laku kaum muslimin dalam berbisnis, maka Islam telah memberikan pedoman agar selalu bertingkah laku yang sesuai dengan etos kerja yang Islami, yakni melakukan aktifitas yang sesuai dengan ajaran Islam.

\section{Makna Etos Kerja Islami}


Membicarakan tentang etos kerja di kalangan birokrat, ilmuan, cendikiawan, dan politisi bukan sesuatu yang baru. Hal ini tidak berarti para pakar telah menyepakati satu definisi yang seragam tentang pengertian etos kerja.

Etos kerja berasal dari kata Yunani. Ethos artinya ciri, sifat atau kebiasaan, adat istiadat, atau juga kecenderungan moral, pandangan hidup yang dimiliki seseorang, suatu kelompok orang atau bangsa. ${ }^{7}$ Dalam Hand Book of Psycologi Term, yang dikutip oleh Ahmad Janan Asifudin disebutkan bahwa etos diartikan sebagai pandangan khas suatu kelompok sosial, sistem nilai yang yang melatarbelakangi adat istiadat dan tata cara suatu komunitas. ${ }^{8}$

Soerjono Soekanto mendefinisikan etos antara lain: a. Nilai-nilai dan ide-ide dari suatu kebudayaan, dan b. Karakter umum suatu kebudayaan. ${ }^{9}$ Nurcholis Madjid memberikan definisi etos ialah karakter dan sikap, kebiasaan serta kepercayaan dan seterusnya yang bersifat khusus tentang seorang individu atau sekelompok manusia. Dari kata etos terambil pula perkataan "etika" yang merujuk pada makna "akhlaq" atau bersifat akhlaqiy, yaitu kualitas esensial seseorang atau suatu kelompok manusia termasuk suatu bangsa. Etos juga berarti jiwa khas suatu kelompok manusia yang daripadanya berkembang pandangan bangsa itu sehubungan dengan baik dan buruk, yakni etika. ${ }^{10}$

Adapun definisi kerja, dalam Kamus Besar Bahasa Indonesia diartikan sebagai kegiatan melakukan sesuatu. ${ }^{11}$ El-Qussy seperti dikutip oleh Ahmad Janan Asifuddin mengemukakan bahwa kegiatan atau perbuatan manusia ada dua jenis. Pertama, perbuatan yang berhubungan dengan kegiatan mental, dan kedua tindakan yang dilakukan dengan secara tidak sengaja. Jenis pertama mempunyai ciri kepentingan, yaitu untuk mencapai maksud atau mewujudkan tujuan tertentu. Sedangkan jenis kedua adalah gerakan random (random movement) seperti terlihat pada gerakan bayi kecil yang tampak tidak beraturan, gerakan refleksi dan gerakan-gerakan lain yang terjadi tanpa dorongan kehendak atau proses pemikiran. ${ }^{12}$

Menurut Mochtar Buchari, etos kerja dapat diartikan sebagai sikap dan pandangan terhadap kerja, kebiasaan kerja; ciri-ciri atau sifat-sifat mengenai cara kerja yang dimiliki seseorang, suatu kelompok manusia atau suatu bangsa. ${ }^{13}$

\section{Etos Kerja Yang Baik}

Bekerja secara mandiri dan Jual beli yang mabrur

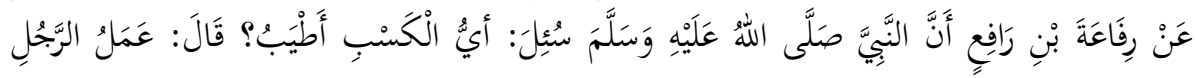

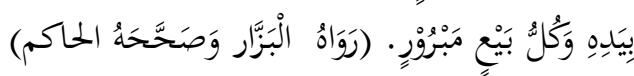

"Rifa'ah bin Rafi' berkata bahwa Nabi SAW, ditanya, "Apa mata pencaharian yang paling baik? "Nabi menjawab: "Seseorang bekerja dengan tangannya dan tiap-tiap jual beli yang bersih." (Diriwayatkan oleh Bazzar disahihkan oleh Hakim). ${ }^{14}$ 
Hadits tersebut sebagai dalil (bukti) penetapan sesuatu yang disenangi oleh tabi'at hati manusia di antara usaha-usaha manusia itu. Hanya saja Rasulullah saw. Ditanya tentang usaha yang paling baik, yaitu usaha yang paling halal dan paling berkah; mengusahakan usaha tangan dari jual beli yang bersih (dari tipu daya, menunjukan bahwa usaha tangan itulah yang paling baik. Yang diriwayatkan oleh Al-Bukhari yang akan dijelaskan nanti, dan Hadis itu menunjukan kebaikan perniagaan yang bersih dari tipu daya.

Di kalangan ulama terdapat perbedaan pendapat tentang usaha yang paling baik itu. Kata Al-Mawardi, bahwa mata pencaharian pokok ialah: pertanian, perniagaan dan perindustrian. Menurut beliau bahwa yang paling sesuai dengan pendapat Imam Syafi'i adalah bhawa usaha yang paling baik itu adalah perdagangan. Menurut beliau, pendapat yang paling kuat menurut saya bahwa usaha yang paling baik itu ialah pertanian, karena lebih dekat kepada tawakkal kepada Allah. Beliau susul (untuk memperkuat argumentasinya) dengan sebuah hadis yang diriwayatkan oleh: Al-Bukhari dan Al-Miqdam yang bersambung sanadnya hingga Rasulullah saw. Beliau bersabda:

$$
\text { (رَوَاهُ الْبْخَارِيّّ) }
$$

"Seseorang tidak memakan suatu makananpun yang lebih baik daripada dia memakan hasil usaha tangannya sendiri; Dan sesungguhnya Nabi Allah Daud a.s. selalu memakan hasil usaha tangannya sendiri." (diriwayatkan oleh Al-Bukhari).

Menurut Imam Nawawi sebaik-baiknya usaha itu adalah sesuatu yang dilakukan dengan sendiri. Jika usaha tangan itu adalah pertanian, maka itulah sebaik-baiknya usaha, karena semuanya mengandung usaha sendiri, di samping karena pertanian itu adalah tawakkal kepada Allah dan manfaatnya untuk umum, baik manusia maupun binatang melata dan burung. ${ }^{15}$

Menurut Al-Hafidz Ibnu Hajar, yang paling tinggi di antara usaha tangan itu adalah apa yang diperoleh dari harta kekayaan orang kafir melalui jihad dan itu adalah usaha Nabi Muhammad saw. Itulah seutama-utamanya usaha, karena usahanya itu demi untuk menegakan Agama Allah.

\section{Pelajaran Yang Terkandung Dalam Hadits Di Atas}

Bila dicermati secara seksama hadits tersebut mengandung beberapa pelajaran penting yang harus dihayati, yaitu:

1) Dalam usaha mencari penghidupan pilihan usaha atau mata pencaharian yang paling baik adalah yang halal dan banyak berkahnya. 
2) Ada dua usaha yang paling baik, yaitu semua usaha yang baik dilakukan dengan tangan sendiri, dan semua perdagangan yang bersih dari tipu-menipu dan cara-cara lain yang tercela.

3) Dalam hadis tersebut terkandung anjuran untuk rajin bekerja dan dilarang bermalas-malasan.

4) Dalam hadits itu juga tersirat perintah untuk memakan sesuatu yang halal lagi baik.

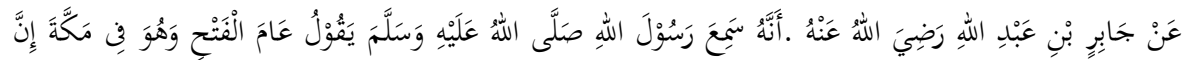

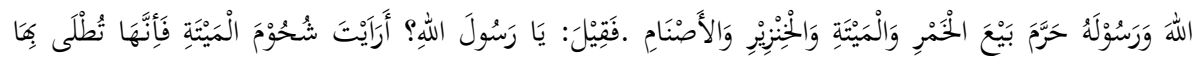

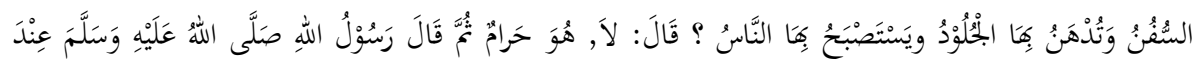

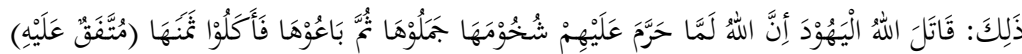

"Dari Jabir bin Abdullah r.a. Sesungguhnya beliau mendengar Rasulullah saw. Bersabda pad atahun penaklukan Makkah sewaktu beliau berada di Makkah itu: Sesungguhnya Allah dan Rasul-Nya telah mengharamkan jual beli khamar (minuman keras), bangaki, daging babi dan berhala; Lalu beliau ditanya: Apa pendapatmu tentang lemak bangkai, karena sesungguhnya lemak bangkai dipakai untuk mencatat perahu, untuk meminyaki kulit dan orang mempergunakannya untuk pelita ?. Beliau bersabda: Tidak boleh; Dia haram; Kemudian Rasulullah saw. Bersabda pada waktu itu :Allah memerangi orang yahudi, karena sesungguhnya setelah Allah mengharamkan lemak bangkai kepada mereka, lalu mereka mencairkannya, kemudian mereka menjualnya lalu mereka memakan harganya". (Muttafaq 'alaih). ${ }^{16}$

Dalam hadits tersebut terdapat dalil (hukum) haramnya sesuatu yang disebutkan itu. Dikatakan bahwa alasan pengharaman jual beli tiga macam yang pertama (yaitu khamar, bangkai dan babi) adalah karena najis; akan tetapi dalildalil yang menunjukan kenajisan kharam itu tidak jelas. Demikian kenajisan bangkai dan babi. Barang siapa yang menetapkan alas an haramnya karena najisnya, maka dia menetapkan huum haram jual beli segala sesuatu yang najis.

Sekelompok ulama berpendapat boleh jual beli pupuk yang najis. Ada juga yang mengatakan hanya boleh bagi pembeli, tidak boleh bagi penjual. Tetapi pendapat dan alasan itu tidak tepat. Perbedaan pendapat ini semuanya hanyalah bagi orang yang menetapkan alasan larangan karena najisnya itu. Yang paling penting, bahwa tidak jelas dalil tentang alasan najisnya itu. Akan tetapi alasannya adalah haramnya itu . Itulah sebabnya Rasulullah saw. Setelah diharamkan lemak itu lepada mereka, lalu beliau enetapkan alasannya adalah karena haramnya itu sendiri beliau tidak menyebutkan alasan lain. 
Ketahuilah bahwa tidak termasuk bangkai, rambutnya dan bulunya, karena rambut dan bulu tidak termasuk zat hidup dan tidak disebut bangkai. Ada yang mengatakan rambut itu mutanajjis dan dapat menjadi suci penyuciannya. Mengenai kebolehan penjualan buluhnya itu adalah menurut Jumhur ulama. Ada yang mengatakan kecuali rambut dan bulu tiga macam yang najis zatnya yaitu rambut dan bulu anjing, babi dan orang kafir. ${ }^{17}$

Tatkala Rasulullah saw. mengungkapkan secara umum pengharaman jual beli bangkai maka pendengarannya mengira Rasulullah mentakhsiskannya dari yang umum itu sebagian bangkai. Lalu orang bertanya: Apa pendapatmu tentang lemak bangkai itu. Maksud orang itu: Jelaskan kepadaku Ya Rasulullah tentang lemak-lemak itu; Apakah lemak bangkai yang bermanfaat itu. Lalu Rasulullah saw. Menjawab: sesungguhnya lemak bangkai itu haram dan beliau menjelaskan kepadanya bahwa lemak bangkai itu tidak keluar hukum haram itu.

Dlomir huwa dalam sabdanya "Hua-hara-mun" itu mungkin kembali kepada jual beli yang berarti jual beli lemak bangkai itu haram dan inilah yang paling jelas karena pembicaraan dalam hadis tersebut adalah tentang jual beli itu dan berdasarkan Hadits yang diriwayatkan oleh Imam Ahmad; Dalam Hadits riwayat Ahmad terdapat matan sebagai berikut:

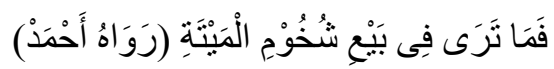

"Lalu apa pendapatmu tentang jual beli lemak bangkai itu?" (H.R. Ahmad).

Mungkin juga dlomir "hua" itu adalah untuk pemanfaatannya yang ditunjukan padanya dengan ucapan penanya "karena sesungguhnya lemak bangkai itu dipergunakan untuk mencatat perahu dan seterusnya Kebanyakan ulama menafsirkan "hua" dengan pemanfaatannya itu. Kata mereka: Tidak boleh dimanfaatkan sedikitpun dari bangkai itu selain kulitnya apabila sudah disamak berdasarkan yang sudah dikemukakan dalam permulaan (jilid) kitab Hadits Tarbiyah ini. Dalil yang menjelaskan samak kulit itu mentakhsiskan keumuman itu, dan itu berdasarkan pendapat bahwa kembalinya dlomir itu adalah kepada pemanfaatan kulit bangkai. Barang siapa yang berkata bahwa dlomir itu adalah kepada pemanfaatan kulit bangkai. Barang siapa yang berkata bahwa dlomir itu kembali kepada jual beli maka dia berdasarkan dalil ijma ulama tentang kebolehan pemberian makanan bangkai kepada anjing sekalipun anjing pemburu bagi orang yang memanfaatkan anjing pemburu itu.

Berdasarkan kedua hadits di atas ada tujuh macam sistem jual beli yang terlarang, yaitu:

a) Muhaqalah (jual beli tanaman atau bijian yang tidak diketahui jumlah dengan sistem borong).

b) Muzabanah (jual beli dengan berebutan atau jual beli anggur basah dengan yang kering dengan takaran). 
c) Mukhabarah (jual beli dengan sistem ijon).

d) Tsunayyah (jual beli sesuatu pengecualian sebagainya tanpa diketahui jumlah atau besar kecilnya yang dikecualikan itu).

e) Mukhadlarah (jual beli buah-buahan atau tanaman yang masih di pohon sebelum nampak baiknya dipanen).

f) Mulmasalah (jual beli berdasarkan rabaan saja, tanpa lihat barang).

g) Munabadzah (jual beli barang dengan saling melemparnya tanpa diketahui kuantitas dan kualitas apa yang dilempar itu).

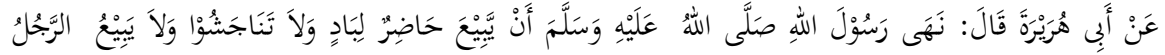

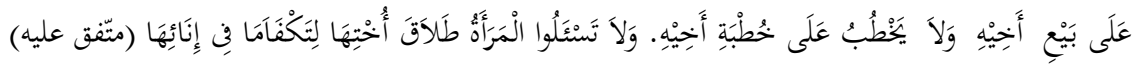

"Dari Abu Hurairah r.a. beliau berkata: Rasulullah SAW, melarang orang kota menjualkan sesuatu untuk orang dusun, beliau melarang memuji-muji barang supaya laku dan mahal, tidak boleh seseorang menjual atas jualan saudaranya, tidak boleh dia meminang atas pinangan saudaranya, tidak boleh seorang wanita meminta thalaq saudaranya agar dia menguasai seisi rumahnya." (Muttafaq 'alaih).

Islam senantiasa mengajarkan kepada umatnya agar berusaha untuk memenuhi kebutuhan hidupnya, tidak dibenarkan seorang muslim berpangku tangan saja atau berdoa mengharapkan rizki datang dari langit tanpa pengiringnya dengan usaha. Namun demikian, tidak dibenarkan pula terlalu mengandalkan kemampuan diri sehingga melupakan pertolongan Allah SWT. Dan tidak mau berdoa kepada-Nya .

Dalam surat Al-Qashash ayat 77 Allah berfirman yang artinya:

"Dan carilah pada apa yang Telah dianugerahkan Allah kepadamu (kebahagiaan) negeri akhirat, dan janganlah kamu melupakan bahagianmu dari (kenikmatan) duniawi dan berbuat baiklah (kepada orang lain) sebagaimana Allah Telah berbuat baik, kepadamu, dan janganlah kamu berbuat kerusakan di (muka) bumi. Sesungguhnya Allah tidak menyukai orang-orang yang berbuat kerusakan".

Oleh karena itu, seorang muslim selayaknya mengeluarkan segala kemampuannya untuk mencari rezeki dengan sekuat tenaga. Akan tetapi, rezeki yang diusahakannya untuk mencari rezeki haruslah halal, tidak mengutamakan penghasilan yang banyak semata, tanpa mengindahkan antara yang telah ditetapkan, tentu saja, pekerjaan apapun tidak dilarang selama tidak bertentangan dengan syari'at Islam. Dalam bekerja, ia menggunakan tangannya atau kemampuannya serta sesuai pula dengan keahliannya, Bekerja dengan menggunakan tangan dan kemampuan sendiri sebagaimana dijelaskan dalam hadis di atas adalah pekerjaan yang paling baik. Dalam hadis lain pun ditanyakan: 


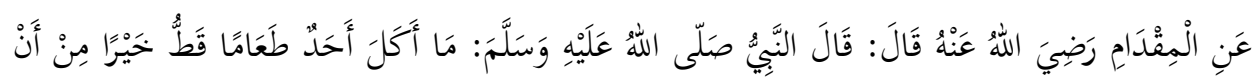

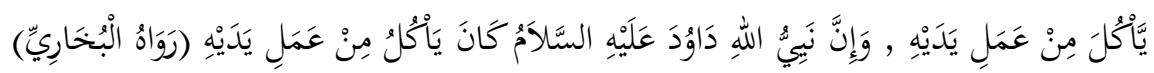

"Dari Miqdam, r.a. Nabi SAW, telah bersabda, "Tidaklah seseorang mkan sesuatu lebih baik dari pada makanan yang dihasilkan melalui sesuatu lebih baik dari pada makanan yang dihasilkan melalui tangannya (usahanya) sendiri. Dan sungguh Nabi Daud A.S. telah makan dari hasil tangannya." (H. R. Bukhari). ${ }^{18}$

Hadis ini lebih mempertegas tentang mulianya orang yang menggunakan tangan dan kemampuannya. Harta yang dihasilkan melalui kerja keras walaupun sedikit dipandang lebih berharga dari pada harta warisan atau pemberian orang lain.

Demikian pula ampunan Allah SWT, senantiasa menyertai orang yang keletihan dalam mencari rezeki, sebagaimana Rasulullah SAW bersabda :

$$
\text { من أ مسى كا لا من عمل يده أ مسى مغفورا له. ( رواه أ ممد ) }
$$

"Barang siapa merasa letih di malam hari karena bekerja, maka ia malam itu ia dipahami."'( H. R. Ahmad ).

Selain itu, Islam pun menjamin dan melindungi mereka yang mau bekerja keras dan menyuruh para majikan untuk menghargai kerja keras orang yang bekerja padanya. Dalam sebuah hadis disebutkan:

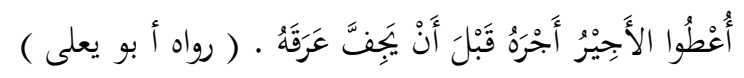

"Berikanlah upah (gaji) kepada pekerja sebelum kering keringatnya."

(H. R. Abu Ya'la).

Dalam kaitan ini Rasulullah SAW, pernah memberikan upah kepada petani sehingga mendapatkan separoh dari hasil tanaman yang digarap. Hal ini sesuai dengan Sabda Nabi:

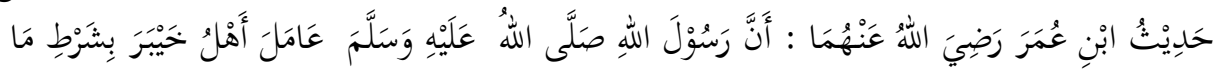

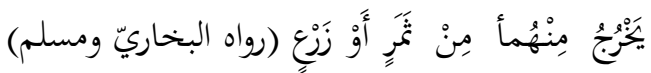

"Diriwayatkan dari Ibnu Umar RA, dia telah berkata: "Sesungguhnya Rasulullah SAWS pernah memberi pekerjaan kepada penduduk Khaibar dengan upah separuh hasil buah-buahan atau tanaman yang dikerjakan." (H.R. Bukhari dan Muslim). ${ }^{19}$

Di antara hikmah dari rezeki yang dihasilkan melalui tangan sendiri. adalah terasa lebih nikmat dari pada hasil kerja orang lain, Juga akan menumbuhkan hidup hemat karena merasakan bagaimana payahnya mencari rezeki. Selain itu, ia 
pun tidak akan lagi menggantungkan hidupnya kepada orang lain, yang belum tentu selamanya ridha dan mampu membiayai hidupnya.

Dalam Hadis di atas pun dinyatakan bahwa penjualan dengan cara yang baik, juga dikategorikan sebagai pekerjaan paling baik, yaitu tidak hanya mengutamakan keuntungan semata sehingga melanggar etika kejujuran dan melanggar rambu-rambu agama. Dia harus ingat bahwa perbuatannya akan dipertanggungjawabkan di hadapan Allah kelak. Dengan demikian, dia tidak mengurangi timbangan, berbohong, menipu, dan lain-lain. Tujuan dengan bukan hanya mencari keuntungan, tetapi juga membantu memenuhi kehidupan orang lain, dan harta yang dihasilkannya tiada lain untuk bekal hidup di dunia dalam rangka mengabdi kepada-Nya.

Menurut Imam Al-Ghazali, manusia dalam hubungannya dengan kehidupan dunia akhirat sebagai pada tiga golongan." ${ }^{20}$

a. Orang-orang yang sukses atau menang, yakni mereka yang lebih menyibukkan dirinya untuk kehidupan di akhirat dari pada kehidupan dunia.

b. Orang-orang yang celaka, yakni mereka yang lebih menyibukan dirinya untuk kehidupan di dunia dari pada kehidupan di akhirat.

c. Orang yang berada di antara keduanya, yakni mereka yang mau menyeimbangkan antara kehidupan di dunia dan kehidupan di akhirat.

Al-Faqih Abu Laits Samarqandi, mengutip pendapat seorang ahli hikmah, "Para pedagang yang tidak memiliki ketiga sifat di bawah ini akan menderita kerugian dunia akhirat:

a) Mulutnya suci dari bohong/laghuwa (main-main) bergurau dan sumpah;

b) Hatinya suci dari penipuan, khianat, dan diri;

c) Jiwanya selalu memelihara shalat jum'at, sahalat berjamaah, selalu menimba ilmu dan mengutamakan rida Allah SWT, dari pada lainnya. ${ }^{21}$

Tentu saja tidak hanya berjual beli yang harus diperhatikan kehalalannya dan kebersihannya, tetapi juga dalam setiap kasab (usaha) hendaknya menjadikan kehalalan dan kebersihan sebagai standar utama dalam mencari rezeki karena bagaimanapun juga, Allah SWT akan meminta pertanggung jawaban kelak di akhirat.

Menurut Al-Faqih Abu Laits Samarqandi; orang yang menginginkan (usaha, harta) yang halal, ia harus memlihara lima perkara, yaitu:

a) Tidak menunda kewajiban Allah SWT, tidak menghambakan apalagi menghadapi kewajibannya sebagai hamba Allah.

b) Tidak ada seorang pun merasa dirugikan atau dianggap akibat usahanya.

c) Memelihara kehormatan (harga) diri dan keluarga, bukan semata menghimpun harta sebanyak-banyaknya.

d) Tidak membinasakan (memaksakan) diri dalam usaha dan 
e) Tidak beranggapan bahwa rezekinya diperoleh dengan usahanya melainkan faktor langsung dari Allah SWT, sedangkan bekerja usaha semata hanya faktor penyebab datangnya rezeki. ${ }^{22}$

\section{Etos Kerja Yang Tidak Baik}

1. Larangan meminta-minta

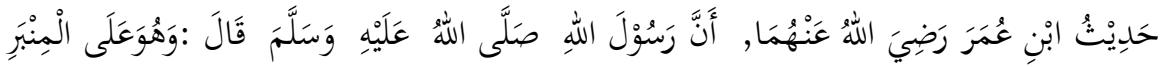

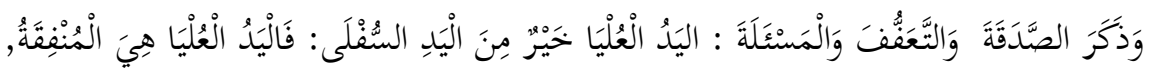

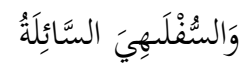

"Umar r.a. berkata, "Ketika Nabi SAW, bersabda di atas mimbar dan menyebut sedekah dan meminta-minta beliau bersabda, "Tangan yang di atas lebih baik dari pada tangan yang di bawah, tangan yang diatas memberi dan tangan yang di bawah meminta. (H,R. Bukhari dan Muslim). ${ }^{23}$

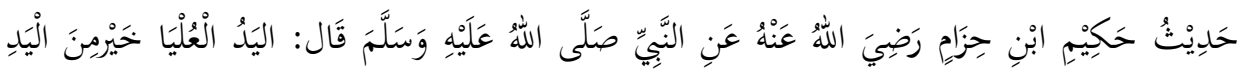

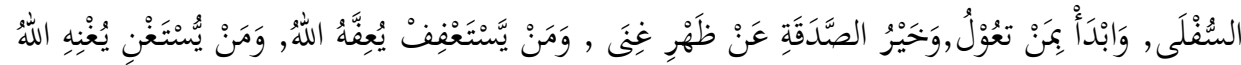

"Hakim bin Hzam berkata, "Nabi SAW. Bersabda, "Tangan yang di atas lebih baik dari pada tangan yang di bawah dandahulukan keluargamu (orangorang yang wajib kamu beri pelajaran), dan sebaik-baiknya sedekah itu dari kekayaan (yang berlebihan), dan siapa yang menjaga kehormatan diri (tidak meminta-minta), maka Allah akan mencukupinya, demikian pula siapa yang beriman merasa sudah cukup maka Allah akan membantu memberinya kekayaan." (Hadits Bukhari dan Muslim). ${ }^{24}$

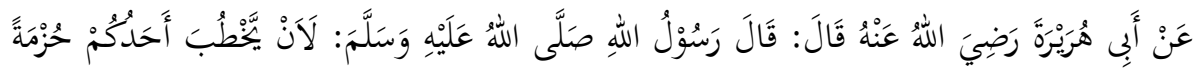

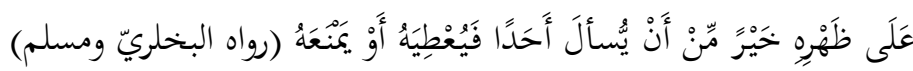

"Abu Hurairah r.a berkata : Rasulullah Saw. Bersabda jika seorang itu pergi mencari kayu, lalu di angakt sedikit kayu di atas punggungnya (yakni untuk dijual di pasar) maka itu lebih baik bagimu dari pada minta kepada seseorangbaik di beri atau ditolak." (Diriwayatkan oleh Imam Bukhari dan Muslim). ${ }^{25}$

Penjelasan singkat :

Islam sangat mencela orang yang mampu untuk berusaha dan memiliki badan yang sehat, tetapi tidak mau berusaha, melainkan hanya menggantungkan hidupnya pada orang lain. Misalnya, dengan cara meminta-minta. Keadaan seperti itu sangat tidak sesuai dengan sifat umat Islam yang mulia dan memiliki kekuatan. 
Sebagaimana diketahui bahwa mencari nafkah yang halal itu wajib bagi setiap muslim, maka setiap muslim hendaknya memperhatikan bidang dan lapangan profesi yang akan dipilihnya. ${ }^{26}$

Kenyataan menunjukkan bahwa apa yang dilakukan oleh sekelompok manusia terdapat pula sejumlah pekerjaan yang haram dan tercela yang bertentangan dengan etos kerja Islami, seperti judi (maisir), pelacuran, bisnis minuman keras dan sebagainya. ${ }^{27}$

Dalam hubungan ini al-Qur'an dan al-Hadits sebagai sumber etos kerja Islami telah memberikan khitthah antara yang halal dan yang haram, antara yang terpuji dan yang tercela. Dalam Hadits riwayat Bukhari dan Muslim disebutkan:

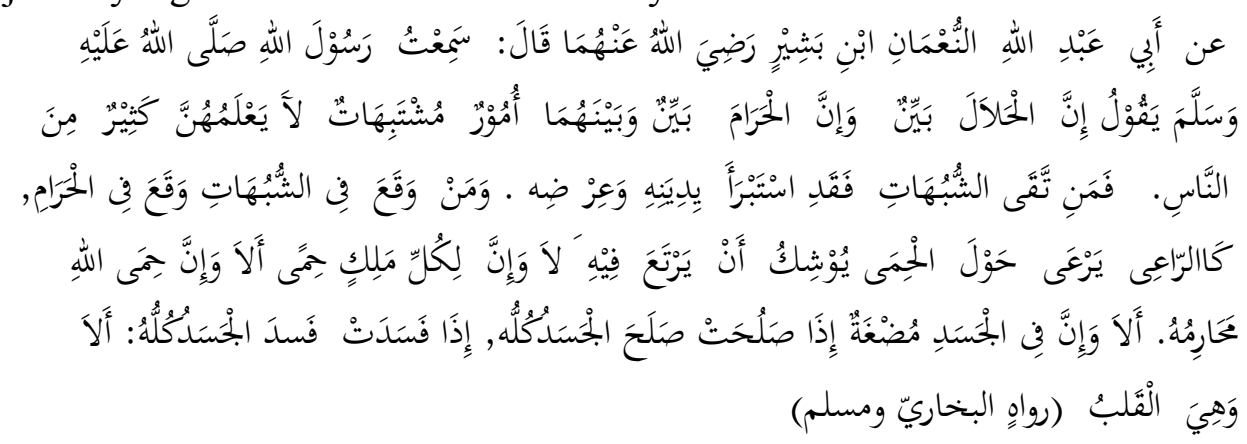

"Dari Abdullah An Nu'man bin Basyir RA. Ia berkata: Aku mendengar Rasulullah SAW, bersabda: "Sesungguhnya yang halal telah jelas, yang haram telah jelas dan di antara keduanya banyak perkara syubhat (yang masih samara) yang kebanyakan manusia tidak mengetahui. Barang siapa berhati-hati terhadap hal yang syubhat, maka sesungguhnya dia telah menyelamatkan agama dan kehormatannya. Dan barang siapa terjerumus kepada hal-hal syubhat, maka ia telah terjerumus pada hal yang haram. Seperti seorang pengembala yang menggembala di sekitar daerah terlarang, maka hampir-hampir ia terjerumus ke dalamnya. Ketahuilah, bahwa tiap-tiap raja mempunyai larangan. Ketahuilah bahwa larangan Allah adalah apa-apa yang diharamkan-Nya. Ketauilah, bahwa di dalam tubuh ada segumpal daging, jika baik, maka baiklah seluruh tubuh, jika rusak, maka rusaklah seluruh tubuh. Ketahuilah, itulah hati" (H.R. Bukhari dan Muslim). ${ }^{28}$

Kalimat "sesungguhnya yang halal telah jelas dan yang haram telah jelas, dan di antara keduanya banyak perkara syubhat (yang masih samara)" maksudnya segala sesuatu terbagi kepada tiga macam hukum. Sesuatu yang ditegaskan halkalnya oleh Allah, maka dia adalah halal, seperti firman Allah dalam Surat alMaidah ayat 5: 


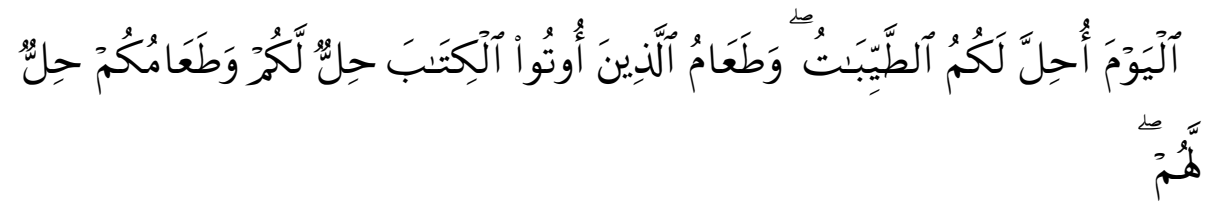

"Pada hari ini dihalalkan bagimu yang baik-baik. makanan (sembelihan) orang-orang yang diberi Al Kitab itu halal bagimu, dan makanan kamu halal (pula) bagi mereka." ${ }^{29}$

Menurut Al-Nawawi seperti diterjemahkan oleh Muhammad Thalib, menyebutkan bahwa sesuatu yang syubhat yaitu setiap hal yang dalil-dalinya masih dalam pembicaraan atau pertentangan; maka menjauhi perbuatan semacam itu termasuk wara'. Para ulama berbeda pendapat mengenai pengertian syubhat yang disyari'atkan Rasulullah SAW, pada hadits tersebut. Sebagian berpendapat bahwa hal semacam itu haram hukumnya berdasarkan sabda Nabi SAW. "barang siapa menjauhi yang syubhat, maka sesungguhnya ia telah menyelamatkan agamanya dan kehormatannya". Barang siapa tidak menyelamatkan agama dan kehormatannya, berarti dia telah terjerumus ke dalam perbuatan haram. ${ }^{30}$

Salah satu hal yang dipandang masih samara-samar adalah orang yang suka minta-minta. Dengan demikian, seorang peminta-minta, yang sebenarnya mampu mencari kasab dengan tangannya, selain telah merendahkan dirinya, ia pun secara tidak langsung telah merendahkan ajaran agamanya yang melarang perbuatan tersebut. Bahkan ia dikategorikan sebagai kufur nikmat karena tidak menggunakan tangan dan anggota badannya untuk berusaha mencari rezeki sebagaimana diperintahkan syara'. Padahal Allah pasti memberikan rezeki kepada setiap makhluk-Nya berusaha.

Dalam ketiga hadis di atas dinyatakan secara tegas bahwa tangan orang yang di atas (pemberi sedekah) lebih baik dari pada tangan yang di bawah (yang diberi). Dengan kata lain, derajat pemberi lebih tinggi dari pada derajat pemintaminta. Maka seyogianya bagi setiap umat Islam yang memiliki kekuatan untuk memberi rezeki, berusaha untuk bekerja apa saja yang penting halal, walaupun suatu pekerjaan dipandang hina dalam pandangan manusia, seperti dicontohkan dalam hadis, yaitu pencari kayu, seseorang yang mencari dan mengikat kayu serta membawanya di atas punggungnya. Tentu saja, hasilnya tidak besar, tetapi pekerjaan ini lebih mulia dibandingkan para pengemis atau orang yang biasa menguntungkan hidupnya pada orang lain, yang mungkin mendapatkan hasil lebih banyak. Padahal yang diperoleh dengan cara seperti ini sama dengan mengumpulkan bara api. ${ }^{31}$ Sebagaimana sabda Rasulullah SAW:

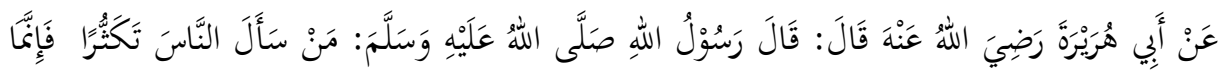

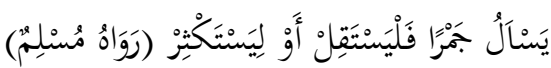


"Abu Hurairah berkata bahwa rasulullah Saw. bersabda, "Barang Siapa yang meminta-minta untuk memperbanyak kekayaanya, ia tidak lain hanya memperbanyak bara api, maka terserah padanya apakah ia akan mengurangi atau memperbanyaknya."(H. R. Muslim)

Dalam hadis di atas pun disinggung tentang etika memberikan bantuan kepada orang lain, yaitu mengutamakan keluarga terdekat, kerabat terdekat, danseterusnya. Selain itu, barang yang akan diberikan haruslah merupakan rezeki lebih, Dengan kata lain, tidak mengutamakan memberi kepada orang lain sementara diri dan keluarganya kelaparan, dengan demikian, maka tidak boleh terlalu kikir ataupun terlalu berlebih-lebihan dalam memberikan sesuatu kepada orang lain.

Bagi orang yang selalu membantu orang lain, di samping akan mendapatkan pahala kelak di akhirat, Allah juga akan mencukupkan rezekinya di dunia. Dengan demikian, pada hakikatnya dia telah memberikan rezekinya untuk kebahagiaan dirinya dan keluarganya Karena Allah SWT. Akan memberikan balasan yang berlipat dan bantuan yang ia berikan kepada orang lain. ${ }^{32}$

Orang yang tidak meminta-minta (percaya diri) dan tidak menggantungkan hidup kepada orang lain meskipun serba kekurangan, lebih terhormat dalam pandangan Allah SWT. Allah akan memuliakannya dengan mencukupinya. Orang Islam harus berusaha memanfaatkan karunia yang diberikan oleh Allah SWT. Berupa kekuatan dan kemampuan dirinya untuk mencukupi hidupnya disertai doa kepada Allah SWT.

Adanya kewajiban berusaha bagi manusia, tidak berarti bahwa Allah SWT. Tidak berkuasa untuk mendatangkan rezeki begitu saja kepada manusia, tetapi dimaksudkan agar manusia menghargai dirinya sendiri dan usahanya, sekaligus agar tidak berlaku semena-mena atau melampaui batas. ${ }^{33}$

2. Mu'min Yang Kuat Mendapat Pujian (AN: 88)

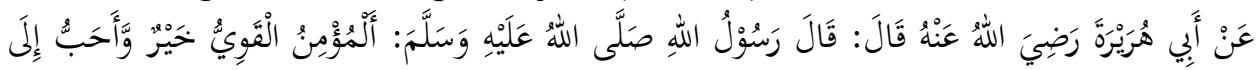

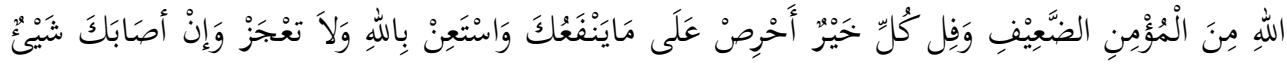

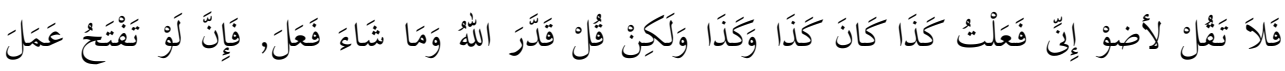

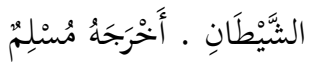

"Abu Hurairah r.a. berkata bahwa Rasulullah Saw bersabda "Orang mukmin yang kuat lebih baik dan lebih dicintai Allah dari pada mukmin yang lemah dan dalam segala sesuatu, ia dipandang lebih baik, raihlah apa yang memberikan manfaat bagimu, minta tolonglah kepada Allah, janganlah lemah! Kalau engkau tertimpa sesuatu, janganlah berkata, kalau aku berbuat begini, pasti begini dan begitu, 
tetapi katakanlah "Allah SWT telah menentukan dan Allah menghendaki aku untuk berbuat karena (kata) "kalau" akan mendorong pada perbuatan setan." (H. R. Muslim).

Penjelasan singkat:

Hadis di atas mengandung tiga perintah dan dua larangan berikut ini:

1. Memperkuat Iman

Keimanan seorang akan membawa kepada kemuliaan baginya, baik di dunia maupun di akhirat, Kalau keimananya kuat dan selalu diikuti dengan melakukan amal saleh, ia akan mendapatkan manisnya iman.

Syaikh Abdur Razzaq bin Abdul Muhsin Al-"Abbad Al Badr dalam Asbab Ziyadati al-Imani wa nuqshanihi, yang diterjemahkan oleh Ahmad S Marzuki mengemukakan bahwa perkara yang paling diinginkan dan disukai serta saling bermanfaat adalah iman. Allah menunjukkan banyak jalan untuk meraih, memperkuat atau menambah iman seseorang. Jika seorang hamba menjalaninya, maka keyakinan dan keimanannya akan bertambah dan semakin kuat. Semua itu telah dijelaskan oleh Allah dalam Kitab-Nya dan oleh Rasul-Nya dalam sunahsunnahnya. ${ }^{34}$

Di antara jalan untuk bertambahnya iman adalah sebagai berikut:

a) Mempelajari ilmu yang bermanfaat yang bersumber dari Kitabullah dan Sunnah Rasulullah SAW.

b) Membaca dan merenungkan Al-Qur'anul Karim.

c) Mengenal nama-nama Allah Paling Indah dan sifat-sifat-Nya Yang Paling Tinggi.

d) Memperhatikan sirah Nabi yang Mulia.

e) Memperhatikan keindahan Ajaran Agama Islam.

f) Membaca Sirah Salaf (Pendahulu) umat ini.

g) Merenungkan ayat-ayat Kauniyah.

h) Bersungguh-sungguh dalam mengerjakan, memperbanyak, dan menjaga Amal Shalih dengan ikhlas, mengharap wajah Allah Ta'ala.

i) Amalan hati.

j) Amalan lisan.

k) Amalan anggota badan. ${ }^{35}$

Menurut Ibnu Rajab, "Ilmu yang bermanfaat adalah menguasai nash-nash Al-Kitab dan As-Sunnah, memahami makna-maknanya. Mengambil atsar dari pasa Shahabat, tabi'in dan tabi't tabi'in yang berkaitan dengan makna-makna alQur'an dan Hadits, serta perkara-perkara yang berkaitan dengan halal, haram, zuhud, kelembutan hati (raqa'ib), dan berbagai pengetahuan lainnya. ${ }^{36}$

Di samping itu juga bersungguh-sungguh dalam membedakan yang shahih dengan yang dhaif dan bersungguh-sungguh dalam memahami makna atsar-atsar 
tersebut. Ilmu yang seperti ini sudah cukup bagi orang yang berakal dan cukup menyibukkan orang yang mencari kesibukan dengan ilmu yang bermanfaat ini. ${ }^{37}$

Setiap orang memiliki tingkat keimanan yang berbeda-beda Ada yang kuat keimanannya yang ditandai dengan sifatnya yang selalu berusaha untuk mengisi keimananya dengan berbagai amal yang diperintahkan oleh Allah SWT. Seperti memerintah kebaikan dan melarang kemungkaran, mengajarkan shalat, mengeluarkan zakat, memberi sedekah, dan lain-lain. Ada pula yang lemah imanya ia tidak mau mengerjakan kewajibannya sebagai orang beriman, seperti yang disebutkan di atas. Tentu saja, orang yang kuat imannya lebih baik dari pada orang yang lemah imannya. Hal ini karena orang yang kuat imannya akan berusaha untuk menjadikan segala aktivitas kehidupannya dalam kebaikan. ${ }^{38}$

Telah disebutkan di atas pembahasan tentang sebab-sebab bertambahnya keimanan. Maka berikut ini akan dibahas mengenai sebab-sebab berkurangnya iman. Sebab, di samping terdapat hal-hal yang dapat menambah dan menumbuhkannya, juga terdapat hal-hal yang dapat mengurangi dan melemahkannya. Seorang muslim, dituntut untuk mengetahui hal-hal yang dapat menambah keimanan agar mampu melakukannya, juga dituntut untuk mengetahui hal-hal yang dapat mengurangi keimanan agar bisa menjauhinya. Hal ini dapat dilihat dari kata-kata berikut:

"Aku mengenal kejelekan bukan untuk melakukan kejelekan itu, tetapi agar dapat menjauhinya. Barangsiapa yang tidak mengenal kejelekan manusia, ia akan terjerumus ke dalamnya. ${ }^{139}$

Disebutkan dalam Ash-Shahihain dari Hudzaifah bin Al-Yaman ra bahwa dia berkata:

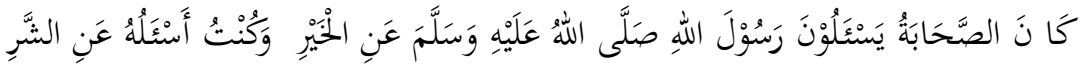

$$
\begin{aligned}
& \text { مُخَفَفَ أَنْ يُدْْ رِكِنِى }
\end{aligned}
$$

"Dulu para sahabat bertanya kepada Rasulullah SAW tentang kebaikan, sedang saya bertanya kepada belkiau tentang kejelekan karena saya khawatir jika kejelekan itu menimpaku."

Ibnu Al-Jauzi berkata: "Mengenal kejelekan itu dalam rangka menghindarkan diri agar tidak terjerumus ke dalamnya. Jadi mempelajari sebabsebab berkurangnya keimanan, mengenal hal-hal yang dapat melemahkannya, dan mengetahui cara-cara untuk melindungi diri dari hal-hal tersebut adalah sebuah keharusan yang harus diperhatikan. Bahkan, mempelajari perkara-perkara yang dapat mengurangi keimanan tidak kalah pentingnya dari pada mempelajari perkara-perkara yang dapat menambah keimanan. ${ }^{41}$

Kuat dan lemahnya seorang mukmin, selain dapat difahami dan perbuatan yang dilakukannya, dapat juga dipahami dalam realitas kehidupan Misalnya, 
dilihat dari segi kekuatan badan, ia tidak loyo, selalu tegar, dan lain-lain Seorang mukmin yang berbeda kuat dan menggunakan kekuatannya itu digunakan untuk beribadah dan membela agamanya lebih baik dari pada mukmin yang lemah badannya sehingga tidak memiliki kekuatan untuk berjuang menegakan agama Allah. $^{42}$

Kekuatan dalam hadis di atas dapat juga di pahami dalam hal ekonomi atau kekayaan. Orang yang rajin berusaha sehingga memperoleh harta benda yang melimpah untuk digunakan bekal beribadah dan mengerjakan amal saleh lebih baik dari pada orang yang tidak mau berusaha sehingga kehidupannya susah.

Secara singkat dapat dijelaskan bahwa Rasulullah Saw. memerintahkan orang yang beriman untuk menghiasi keimananya dengan berbagai amal saleh serta memelihara badannya agar kuat, dan rajin berusaha sehingga kuat perekonomiannya. Tentu saja tetap berusaha untuk menjauhi segala bentuk kemaksiatan supaya mendapat kebahagiaan di dunia dan akhirat. ${ }^{43}$

\section{Perintah Untuk Memanfaatkan Waktu}

Rasulullah SAW, menginginkan agar umatnya mendapat kebahagiaan di dunia dan di akhirat, Oleh karena itu beliau memerintahkan umatnya untuk memanfaatkan waktu seefektif mungkin bagi kegiatan-kegiatan yang bermanfaat, baik untuk kehidupan di dunia maupun akhirat.

Banyak sekali aktivitas yang bermanfaat bagi kehidupan seorang mukmin, seperti mencari ilmu, membaca, bekerja mencari rezeki yang halal, berolah raga, memperbanyak amalan sunnah, dan lain-lain Oleh karena itu, jangan menghambur-hamburkan waktu membantu kegiatan yang tidak bermanfaat, bermalas-malasan, melamun, banyak menonton TV yang acarannya kurang bermanfaat, dan lain-lain.

Dalam kehidupan di masyarakat, orang-orang yang sukses dan berhasil dalam hidupnya adalah mereka yang senantiasa menggunakan waktunya untuk kegiatan yang bermanfaat dan selalu serius dalam mengerjakan sesuatu, mereka menganggap bahwa waktu adalah uang (time is money), Sebaliknya, orang-orang yang suka tidak berguna, tidak akan meraih kesuksesan bahkan ia akan tergilas oleh zaman. Pepatah Arab menyatakan:

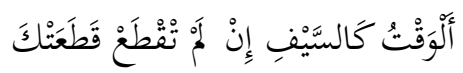

"Waktu itu bagaikan pedang, jika kamu tidak memanfaatkannya (menggunakannya untuk memotong), ia akan memotongmu (mengilasmu)."

Jadi sebagai insan yang berfikir hendaknya pandai-pandai menggunakan waktu yang telah diberikan oleh Allah SWT, untuk diaplikasikan dalam perbuatan yang bermanfaat dan berhasil guna, sebab, jika kita terlena dengan waktu maka kita akan ketinggalan. 
Iqbal dalam Asrar Al-Khudi berkata, “ Berhenti tidak ada tempat untuk jalan ini dan sikap lamban berarti mati, Mereka yang bergerak, akan maju ke muka, sedangkan mereka yang menunggu sekalipun sejenak pasti tergilas. ${ }^{44}$

\section{Memohon Pertolongan Allah SWT.}

Manusia hanyalah diwajibkan untuk beriktia, sedangkan yang memutuskan keberhasilannya adalah Allah SWT. Orang mukmin sangat ditekankan untuk memperbanyak doa agar Allah SWT. Dengan berdo'a kepada Allah insya Allah akan mengabulkan do'a kita. Namun sekali lagi kita harus selalu berusaha, sesuai Firman Allah yang tercantum dalam Surat Ar-Ra'du ayat 11:

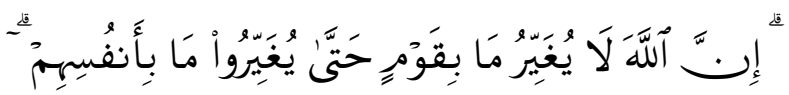

"...Sesungguhnya Allah tidak merobah keadaan sesuatu kaum sehingga mereka merobah keadaan yang ada pada diri mereka sendiri. " 45

Di samping tetap berusaha jangan lupa berdo'a kepada Allah, sejalan dengan Firman Allah dalam surat al-Fatihah ayat 5:

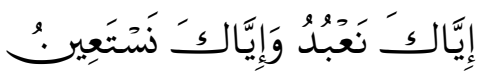

"Hanya Engkaulah yang kami sembah, dan Hanya kepada Engkaulah kami meminta pertolongan."46

Kata $N a ' b u d u$ diambil dari kata 'ibaadat: kepatuhan dan ketundukkan yang ditimbulkan oleh perasaan terhadap kebesaran Allah, sebagai Tuhan yang disembah, Karena berkeyakinan bahwa Allah mempunyai kekuasaan yang mutlak terhadapnya.

Nasta'iin (minta pertolongan), terambil dari kata isti'aanah: mengharapkan bantuan untuk dapat menyelesaikan suatu pekerjaan yang tidak sanggup dikerjakan dengan tenaga sendiri.

Dalam ayat tersebut pernyataan beribadah disejajarkan dengan pertolongan memohon pertolongan. Orang-orang yang hanya beribadah saja kepada-Nya, namun tidak pernah memohon pertolongan keimananya, masih dipertanyakan. Ini karena dia dapat dianggap orang yang tidak memerlukan pertolongan Allah SWT.

Salah satu yang harus kita lakukan dalam kehidupan sebagai muslim adalah berdo'a kepada Allah SWT. Do'a bukan hanya menunjukkan kita merendahkan diri kepada Allah, tapi memang kita merasa betul-betul memerlukan bantuan dan pertolongan-Nya, karena Allah adalah segala-galanya, sedangkan kita amat memerlukan dan bergantung kepada-Nya. Salah satu dari sekian banyak do'a yang diajarkan Rasulullah sebagaimana yang yang diriwayatkan oleh Ahmad, Muslim dan Nasa'i adalah: 
"Ya Allah, aku berlindung kepada-mu dari ilmu yang tak bermanfaat, dari hati yang tak khusyu' dan jiwa yang tak pernah merasa puas serta do'a yang tak terkabul. ${ }^{\prime \prime 7}$

Empat permintaan tersebut rasanya penting untuk difahami agar dalam do'a yang kita panjatkan selalu dengan penghayatan dan kesungguhan, bukan sekedar kalimat-kalimat yang dihafal. Permintaan pertama adalah berlindung kepada Allah dari kemungkinan memiliki ilmu yang tidak bermanfaat, yakni ilmu yang tidak kita amalkan dan tidak mau kita ajarkan kepada orang lain. Ilmu yang bermanfaat adalah ilmu yang membuat kita semakin menyadari kebodohan diri kita sendiri lalu kita akan terus memperbanyaknya serta ilmu yang membuat kita semakin tawaddu' atau rendah hati bukan malah membuat kita menjadi takabbur (sombong). Di samping itu, ilmu yang bermanfaat juga membuat kita semakin dapat menempuh jalan hidup sebagaimana yang ditentukan Allah SWT. Karena itu, azab yang paling pedih dalam kehidupan akhirat adalah apabila orang mempunyai ilmu (alim) tapi tidak memanfaatkan ilmu itu sebagaimana mestinya. ${ }^{48}$

Kedua, yang menjadi permintaan penting yang diajarkan Rasulullah SAW, adalah berlindung kepada Allah dari hati yang tak khusu'. Secara harfiyah, khusu' artinya tunduk, rendah dan takluk, ini berarti hati yang khusu' adalah hati yang merasa dekat dengan Allah karena tunduk, merendahkan diri dan takut kepadaNya. Dari hati yang khusu' ini, akan lahir sikap dan prilaku yang tunduk dfan patuh kepada Allah SWT, sehingga orang yang hatinya khusu' akan selalu melaksanakan apa yang diperintahkan oleh Allah SWT, dan meninggalkan segala bentuk larangan-Nya dalam situasi dan kondisi yang bagaimanapun juga serta di manapun di berada. ${ }^{49}$

Permintaan penting yang ketiga adalah berlindung kepada Allah dari jiwa yang tak pernah merasa puas, hal ini karena sebenarnya Allah SWT, telah memberikan kenikmatan kepada kita nikmat yang amat banyak, bahkan banyaknya nikmat itu sampai tidak bisa kita hitung satu persatu. Sedangkan permintaan keempat, dianatara do'a penting yang harus dipanjatkan adalah berlindung kepada Allah dari kemungkinan do'a yang tidak terkabul..$^{50}$ Beberapa hal yang berkaitan dengan nikmat di bawah ini akan dipaparkan dalam beberapa ayat Al-Qur'an. Firman Allah dalam surat Ibrahim ayat 34:

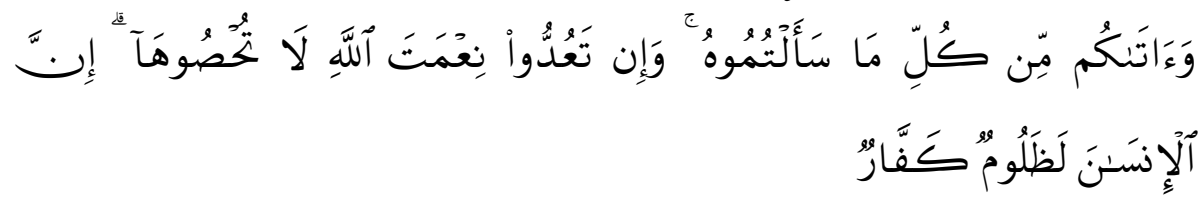

"Dan dia Telah memberikan kepadamu (keperluanтu) dan segala apa yang kamu mohonkan kepadanya. dan jika kamu menghitung nikmat Allah, tidaklah dapat kamu menghinggakannya. Sesungguhnya manusia itu, sangat zalim dan sangat mengingkari (nikmat Allah). ",51 
Ayat tersebut didahului oleh ayat-ayat sebelumnya yang berbicara tentang Allah yang mencipta dan mengatur alam ini, menciptakan manusia sebagai penghuni bumi; menurunkan hujan dari langit; mengeluarkan buah-buahan yang beraneka macam dari perut bumi sebagai rezeki bagi umat manusia, memudahkan bahtera berlayar mengarungi samudera, menciptakan gunung-gunung dan sungaisungai; menundukkan siang dan malam, serta matahari dan bulan, dan mendatangkan apa saja yang diminta ataupun yang tidak diminta oleh manusia. Segala yang disebutkan itu, merupakan nikmat-nikmat besar dari Allah, yang mencakup nikmat material dan immaterial (Q.S. Ibrahim 14: 32-33). ${ }^{52}$

Pemberian nikmat kepada manusia bertujuan untuk menjadi ujian atau cobaan, apakah mereka sanggup mensyukuri nikmat itu ataukah justru mengkufurinya. ${ }^{53}$ Hal ini sesuai dengan Firman Allah (Q.S.al-Naml: 40):

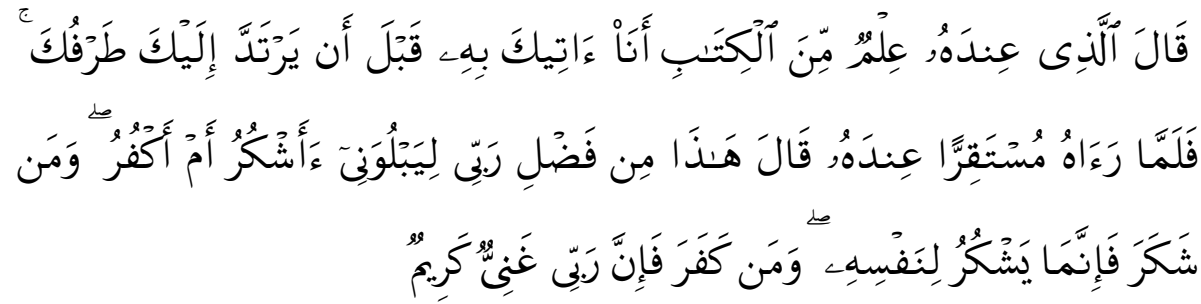

"Berkatalah seorang yang mempunyai ilmu dari AI Kitab:"Aku akan membawa singgasana itu kepadamu sebelum matamu berkedip". Maka tatkala Sulaiman melihat singgasana itu terletak di hadapannya, iapun berkata: "Ini termasuk kurnia Tuhanku untuk mencoba Aku apakah Aku bersyukur atau mengingkari (akan nikmatNya). dan barangsiapa yang bersyukur Maka Sesungguhnya dia bersyukur untuk (kebaikan) dirinya sendiri dan barangsiapa yang ingkar, Maka Sesungguhnya Tuhanku Maha Kaya lagi Maha Mulia. ${ }^{154}$

Bila manusia mensyukuri nikmat-nikmat yang dianugerahkan kepadanya, maka manfaat dari kesyukurannya itu akan kembali kepada dirinya, dan rizki dari Allah akan bertambah bahkan dilipatgandakan. Sebaliknya, bila manusia mengkufuri niukmat-nikmat-Nya, maka kekufurannya itu tidak akan mempengaruhi kekuasaan Allah sebagai penguasa mutlak dan pemilik sebenarnya dari alam semesta ini. ${ }^{55}$ Dalam surat Alim Imran ayat 97 Allah berfirman:

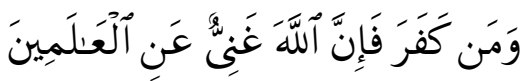

"Barangsiapa mengingkari (kewajiban haji), maka Sesungguhnya Allah Maha Kaya (Tidak memerlukan sesuatu) dari semesta alam. " 56

Bahkan dengan kekufurannya itu, manusia akan mendapat adzab Allah yang sangat pedih. Hal ini seperti tersebut dalam Firman Allah (Q.S. Ibrahim: 7): 


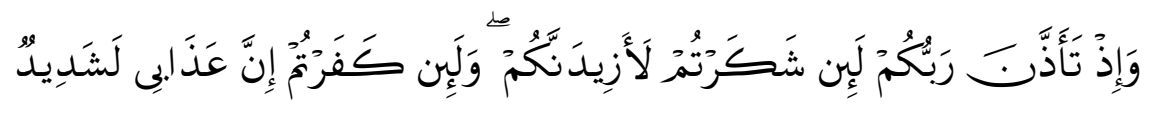

"Dan (ingatlah juga), tatkala Tuhanmu memaklumkan; "Sesungguhnya jika kamu bersyukur, pasti kami akan menambah (nikmat) kepadamu, dan jika kamu mengingkari (nikmat-Ku), Maka Sesungguhnya azab-Ku sangat pedih. ${ }^{157}$

Dari sekian banyak nikmat yang Allah anugerahkan kepada manusia, ada tiga nikmat inti dan penting pada diri manusia yang seringkali tidak disyukuri dan disalahfungsikan kegunaannya. Nikmat-nikmat itu ialah pendengaran (as-Sam'u), penglihatan (al-Basharu), dan hati/akal fikiran (Al-Fu'adu) ${ }^{58}$

\section{Larangan Membiarkan Kemalasan}

Telah dijelaskan di atas bahwa Islam sangat menganjurkan umatnya untuk berusaha dan bekerja sehingga menjadi orang yang kuat dalam berbagai hal, baik iman, jiwa, raga, badan, harta, dan lain-lain.

Kelemahan seseorang berawal dari kemalasannya. Orang yang bodoh malas mencari ilmu, orang yang lemah badannya karena ia tidak rajin berolah raga, orang yang miskin hartanya karena ia tidak mau bekerja, dan lain-lain.

Setiap orang harus berusaha untuk mengubah segala kelemahannya yang ada pada dirinya karena Allah SWT. Tidak akan mengubahnya. (Ar-Ra'du :11).

5. Larangan untuk menyatakan "kalau" (seandainya begini dan begitu pasti halnya begini).

Dalam berusaha, tidak dapat dipastikan bahwa selamanya berhasil, Suatu waktu, seseorang pasti mendapatkan kegagalan dalam mengahadapi keadaan seperti itu, Islam menganjurkan untuk menyerahkan menjadi kehendak-Nya dan manusia hanyalah berusaha untuk berikhtiar. ${ }^{59}$

Pernyataan "kalau begini dan begitu" merupakan godaan setan untuk mendahului kehendak Allah SWT. Tidak menghendaki keberhasilannya.

Pemahaman Al-Hadis:

Orang mukmin yang kuat, baik dalam keimanan, badan, kekayaan, dan lainlain lebih baik dan lebih dicintai Allah daripada mukmin yang lemah. Seorang mukmin harus berusaha untuk memanfaatkan kesempatan terhadap segala sesuatu yang bermanfaat, yang dengan mengisi waktunya dengan aktivitas yang memberikan manfaat.

Setelah berusaha dengan baik, seorang mukmin harus bertawakal, dan berdoa kepada Allah SWT. Dialah yang berperan dalam menentukan sesuatu, sedangkan manusia hanyalah beriktiar. 
Jika ditimpa kegagalan, seorang mukmin tidak boleh berkata, "Kalau aku berbuat begini, pasti begini dan begitu, "Akan tetapi, hendaknya ia berkata: "Allah SWT, telah menentukan dan Allah menghendaki hal itu. "Karena pernyataan "kalau" berarti mendahului kehendak Allah dan termasuk salah satu perbuatan setan.

\section{Penutup}

Dari uraian di atas dapat disimpulkan bahwa dalam kehidupan ini aktivitas yang bermanfaat bagi kehidupan seorang mukmin, seperti mencari ilmu, membaca, bekerja mencari rezeki yang halal, berolahraga, memperbanyak amalan sunnah, dan lain-lain. Oleh karena itu, jangan menghambur-hamburkan waktu membantu kegiatan yang tidak bermanfaat, bermalas-malasan, melamun, banyak menonton TV yang acaranya kurang bermanfaat, dan lain-lain.

Dalam kehidupan di masyarakat, orang-orang yang sukses dan berhasil dalam hidupnya adalah mereka yang senantiasa menggunakan waktunya untuk kegiatan yang bermanfaat dan selalu serius dalam mengerjakan sesuatu, mereka menganggap bahwa waktu adalah uang (time is money), Sebaliknya, orang-orang yang suka melakukan sesuatu yang tidak berguna, tidak akan meraih kesuksesan bahkan ia akan tergilas oleh zaman. Usaha yang terbaik dalam tuntunan Islam adalah bekerja dengan tangannya sendiri dan setiap jual beli yang mabrur.

\section{Catatan Akhir:}

${ }^{1}$ Sriyanti dkk, Etika Membangun Masyarakat Islam Modern, (Yogyakarta: Graha Ilmu, 2007), cet ke-2, hal. 139.

2 Dochak Latief, Pengantar Dalam Etos Kerja Islami (Ahmad Janan Asifudin), (Surakarta: Universitas Muhammadiyah Press, 2004), cet ke-1, hal. Vi.

${ }^{3}$ Q.S. Al-Jumu'ah ayat 10.

${ }_{5}^{4}$ Dochak Latief, Pengantar, Op-Cit, hal.vi

${ }^{5}$ Hasbi Al-Shiddieqi dkk, Al-Qur'an dan Terjemahnya, (Jakarta: Yayasan Penerjemah Al-Qur'an, Depag RI, 1991), hal. 69

${ }^{6}$ Abu Bakar Muhammad, Hadits Tarbiyah (Surabaya: Al-Ikhlas, 1995), hal. 192.

${ }^{7}$ Mochtar Buchori, Penelitian Pendidikan dan Pendidikan Islam di Indonesia, (Jakarta: IKIP Muhammadiyah Press, 1994), hal. 6.

${ }^{8}$ Ahmad Janan Asifuddin, Etos Kerja Islami, (Surakarta: Muhammadiyah University Press, 2004), cet ke-1, hal. 26.

${ }^{9}$ Soerjono Soekanto, Kamus Sosiologi, (Jakarta: Rajawali Press, 1983), hal. 174.

${ }^{10}$ Nurcholis Madjid, Islam, Doktrin dan Peradaban, (Jakarta: Yayasan Wakaf Paramadina, 1995), cet' ke-3, hal. 410.

${ }^{11}$ Anton Muliono dkk, Kamus Besar Bahasa Indonesia, (Jakarta: Balai Pustaka, 1994), cet. Ke-3, hal. 488.

${ }^{12}$ Ahmad Janan Asifudin, Etos, Op. Cit, hal. 27.

${ }^{13}$ Mochtar Buchori, Penelitian Pendidikan,Op. Cit, hal. 6. 
${ }^{14}$ Ibid., hal. 193.

${ }^{15}$ Ibid, hal. 194.

${ }^{16}$ Abu Bakar Muhamad, Hadits Tarbiyah, Surabaya: Al-Ihlas, 1995, hal. 195-196

${ }^{17}$ Ibid.

${ }^{18}$ Hamzah Ya'qub, Etos Kerja Islami, (Jakarta, Pedoman Ilmu Jaya, 2001), hal. 42.

${ }^{19}$ Ahmad Mudjab Mahalli, Hadits-hadits Muttafaq 'alaih Bagian Munakahat dan Mu'amalat (Jakarta, Prenada Media, 2004), hal. 103.

${ }^{20}$ Rachmat Syafi'i, Op. Cit, ha. 117

${ }^{21}$ Ibid

${ }^{22}$ Ibid, hal. 118.

${ }^{23}$ Muhammad Fuad Abdul Baqi, Al-Lu'lu wa al-Marjan, Terjemah H. Salim Bahreisy (Surabaya, Bina Ilmu, 1996) hal. 318.

${ }^{24}$ Ibid.

${ }^{25}$ Ibid, hal. 321.

${ }^{26}$ Hamzah Ya'kub, Etos Kerja Islami, Petunjuk Pekerjaan Yang Halal dan Haram dalam Syari'at Islam, (Jakarta, Media Ilmu Jaya, 2003) hal. 26.

${ }^{27}$ Ibid.

${ }^{28}$ Imam Nawawi, Syarah Hadits Arbain, Pensyarat Ibnu Daqiq al 'Ied, terjemah Muhammad Thalib (Yogyakarta, Media Hidayah, 2001), hal. 44.

${ }^{29}$ Hasbi Ash-Shiddieqi, Op. Cit, hal. 158.

${ }^{30}$ Imam Nawawai, Hadits Arbain, Op. Cit, hal. 45.

${ }^{31}$ Rachmat Syafi'i, Op. Cit, hal. 123

${ }^{32}$ Ibid.,

${ }^{33}$ Ibid, hal. 124

${ }^{34}$ Syaikh Abdur Razzaq bin Abdul Muhsin Al-'Abbad Al Badr dalam Asbab Ziyadati al-Imani wa nuqshanihi, yang diterjemahkan oleh Ahmad S Marzuki (Yogyakarta, Media Hidayah, 2006) halaman 15

${ }^{35}$ Ringkasan penulis dari Manajemen Iman (Asbab Ziyadah al-Iman wa nuqshanih, Karya Syaikh Abdur Razzaq bin Abdul Muhsin Al-Abbad Al Badr, dari hal 15 sampai 95

${ }^{36}$ Ibid

${ }^{37} \mathrm{Ibid}, \mathrm{hlm} .16$

${ }^{38}$ Rachmat Syafi'i, Op-Cit, hlm.128

${ }^{39}$ Syaikh Abdur Razzaq bin Abdul Muhsin Al'Abbad Al Badr, Op-Cit, hlm.105

${ }^{40}$ Ibid

${ }^{41}$ Ibid, hal. 106.

${ }^{42}$ Rachmat Syafi'i, Op. Cit, hal. 128.

43 Ibid.

${ }^{44}$ Rachmat Syafi'i, Op. Cit, hal. 129.

${ }^{45}$ Hasbi Ash-Shiddieqi, Op. Cit, hal. 370.

${ }^{46}$ Ibid, hal. 6.

${ }^{47}$ Ahmad Yani, Empat Permintaan (Jakarta, Bultin Khairu Ummah, LPPD Khairu Ummah, 2000) hal. 1

${ }^{48}$ Ibid.

${ }^{49}$ Ibid, hal. 2

${ }^{50}$ Ibid.

${ }^{51}$ Hasbi Ash-Shiddieqi, Op. Cit, hal. 385.

${ }^{52}$ Abdullah Faqih S, Hubungan Ibadah dengan Syukur Nikmat, (Jakarta, Bultin Dakwah, Dewan Dakwah Islamiyah Indonesia, 1996) hal. 2.

${ }^{53}$ Ibid. 
${ }^{54}$ Hasbi Ash-Shiddieqi, Op. Cit, hal. 598.

${ }^{55}$ Abdullah Faqih S, Op. Cit, hal. 2.

${ }^{56}$ Hasbi Ash-Shiddieqi, Op. Cit, hal. 92.

${ }^{57}$ Ibid, hal. 380.

${ }^{58}$ Abullah Faqih S, Op. Cit, hal. 2.

59 Rachmat Syafi'i, Op. Cit, hal. 131.

\section{DAFTAR PUSTAKA}

Al-Shiddieqi, Hasbi, et.al, Al-Qur'an dan Terjemahnya, Jakarta: Yayasan Penerjemah Al-Qur'an, Depag RI, 1991.

Asifuddin, Ahmad Janan, Etos Kerja Islami, cet ke-1. Surakarta: Muhammadiyah University Press, 2004.

Baqi, Muhammad Fuad Abdul, Al-Lu'lu wa al-Marjan, Terjemah Salim Bahreisy Surabaya: Bina Ilmu, 1996.

Buchori, Mochtar, Penelitian Pendidikan dan Pendidikan Islam di Indonesia, Jakarta: IKIP Muhammadiyah Press, 1994.

Faqih S, Abdullah, Hubungan Ibadah dengan Syukur Nikmat, Jakarta: Buletin Dakwah, Dewan Dakwah Islamiyah Indonesia, 1996.

Latief, Dochak, Pengantar dalam Ektos Kerja Islami, cet ke-1. (Ahmad Janan Asifudin), Surakarta: Universitas Muhammadiyah Press, 2004.

Muhammad, Abu Bakar, Hadits Tarbiyah, Surabaya: Al-Ikhlas, 1995.

Madjid, Nurcholis, Islam, Doktrin dan Peradaban, cet' ke-3, Jakarta: Yayasan Wakaf Paramadina, 1995.

Muliono, Anton, et.al., Kamus Besar Bahasa Indonesia, cet. Ke-3, Jakarta: Balai Pustaka, 1994.

Mahalli, Ahmad Mudjab, Hadits-Hadits Muttafaq 'alaih Bagian Munakahat dan Mu'amalat, Jakarta: Prenada Media, 2004. 
Nawawi, Imam, Syarah Hadits Arbain, Pensyarat Ibnu Daqiq al 'Ied, terjemah Muhammad Thalib, Yogyakarta: Media Hidayah, 2001.

Razzaq, Syaikh Abdur, bin Abdul Muhsin Al-'Abbad Al Badr dalam Asbab Ziyadati al-Imani wa nuqshanihi, yang diterjemahkan oleh Ahmad S Marzuki, Yogyakarta: Media Hidayah, 2006.

Soekanto, Soerjono, Kamus Sosiologi, Jakarta: Rajawali Press, 1983.

Sriyanti, et.al, Etika Membangun Masyarakat Islam Modern, cet ke-2, Yogyakarta: Graha Ilmu, 2007.

Ya'kub, Hamzah, Etos Kerja Islami, Petunjuk Pekerjaan yang Halal dan Haram Dalam Syari'at Islam, Jakarta: Media Ilmu Jaya, 2003.

Yani, Ahmad, Empat Permintaan, Jakarta: Buletin Khairu Ummah, LPPD Khairu Ummah, 2000.

Sohari, dosen pada Fakultas Syari'ah dan Ekonomi Islam IAIN Sultan Maulana Hasanuddin Banten. 